\title{
Strategic Formulation Analysis to Build a New Business Startup "Jamu Partnership" in Indonesia
}

\author{
Erna Setiyawati ${ }^{1}$, Andhika Saputra ${ }^{2}$, Rhian Indradewa ${ }^{3}$, \\ Tantri Yanuar Rahmat Syah $^{4}$
}

1,2,3,4 Department Management, Faculty Economic and Business, Esa Unggul University, Jakarta - Indonesia

Corresponding Author: Erna Setiyawati

\begin{abstract}
Background - PT Oesodo Alam Mandiri (PT OAM) is a startup company that was established to provide solutions to business opportunities and problems that are being faced by people in Indonesia. Before starting a business, it is necessary to analyze both internal and external factors, also carry out strategy formulation. The results of this analysis will assist in determining the right strategy and business model. Through the right strategy and business model, a newly established startup company will be able to compete and be sustainable.

Method - Using Value Proposition Canvas, EFE, IFE, VRIO, CPM, SWOT, IE, QSPM, Porter's Generic Strategy and Lean Business Canvas Model.

Result - This analysis helps to determine the right business model for jamu partnership startup company.
\end{abstract}

Keywords: Startup, Value Proposition Canvas, Lean Business Model Canvas, Jamu, Indonesia.

\section{INTRODUCTION}

According to a survey by insurance institutions, $73 \%$ of people in Indonesia really care about health and make health a lifestyle. According to Contoyannis, P., \& Jones (2004), lifestyle is a set of behaviors that are considered to affect health a priori and are generally considered to involve a large number of free choices. One lifestyle that is being promoted is the lifestyle of drinking jamu. Unfortunately, existing jamu are still constrained by the stigma of a bitter taste. Jamu is a traditional Indonesian health drink (Saputra, 2021). This is also supported by the Decree of the Minister of Health of the Republic of Indonesia Number 76 of 2015 concerning fitness and health tourism in the form of jamu cafes. Based on the survey, the jamu industry increased $7.4 \%$ every year. Meanwhile, the desire of people in Indonesia to become entrepreneurs through SMEs also increases by $2.6 \%$ every year. The use of their own business brand is still a problem for business beginners, including the lack of adequate mentoring. PT Oesodo Alam Mandiri (PT OAM) is a startup company that came to provide solutions to the problems above. Before starting the business, the company's founding team conducted a preliminary analysis to determine the right business model. Understanding the internal and external environment through systematic acquisition, examination, analysis, interpretation, and exploitation of information in business can support the company's goals (Chung et al., 2005).

\section{MATERIALS AND METHODS Identify Problems and Opportunities}

In the early stages, the PT OAM team identified problems and opportunities first, this identification is done through analysis of customer jobs (jobs to be done), customer pains and customer gains. Customer jobs describe what customers are trying to accomplish in their work and life, customer pains describe poor outcomes, risks, and obstacles associated with the 
customer's work, whereas and customer gains describe the results customers want to achieve or the tangible benefits they seek (Osterwalder, 2014). Furthermore, the PT OAM team determined the value proposition canvas, this is important because it is at the core of everything that focuses on organizational values, sharpens the way the organization works by focusing on activities to serve customers profitably (Barnes, C., Blake, H., \& Pinder, 2009; Clark etal., 2012). The value proposition canvas also explicitly helps how to create value for customers, helping companies design products and services that customers want (Osterwalder, 2014). The value proposition canvas includes (1) products $\&$ services based on the value proposition, (2) profit creators, (3) pain relievers (Lindič, J., \& Da Silva, 2011).

\section{Business Solutions}

Business solutions are provided based on the identification of problems and opportunities consisting of pain relievers, gain creators and products and services provided. Pain reliever describes how products and services reduce to the customer. Gain creators explain how products and services create customer benefits. Meanwhile, to answer customer jobs, products and services will be built based on a value proposition (Osterwalder, 2014).

\section{External Factor Analysis}

Based on business solutions, this activity is used to measure the value of competitive forces, perform PEST analysis, and determine opportunity and threats. According to Grant (2010), porter's five forces include three sources of "horizontal" competition such as competition from substitutes, competition from competitors, and competition from established competitors; and two sources of "vertical" competition such as supplier power and buyer power. According to David (2012), PEST analysis consists of political, economic, social and technological.
Analysis external factors will support innovation, the emergence of new ideas (Choe, 2003). The results of this analysis are identifying opportunities and threats in the business (Fristanto etal., 2020).

\section{Internal Factor Analysis}

Based on business solutions, this activity includes analysis of demand, competition, resources and capabilities, determining strengths and weaknesses, and determining the company's competitive advantage. According to Grant (2010), to survive and thrive in an industry, a company must meet two criteria: first, it must be able to meet what customers want to buy and second, it must be able to survive in the competition. It is important to distinguish between enterprise resources and capabilities. Resources are productive assets owned by companies, while capabilities are things that companies can do. Activities to build competitive advantage through the development of resources and capabilities can be the main strategy in facing competition (Grant, 2010). The results of this analysis are identifying strengths and weaknesses in the business.

\section{Strategic Planning}

After the business solution, external and internal factors are determined, then the strategic planning is analyzed further. Strategic planning carried out includes determining the objective. Perform matching stage (SWOT, IE matrix), QSPM decision stage, porter's generic strategy (Kurniawan etal., 2020; Arifin etal., 2019; Haq \& Indradewa, 2020). Finaly making a lean business model canvas.

\section{DISCUSSION}

At this discussion stage, there will be a detailed discussion of each section which includes determining the value proposition canvas, identifying problems and opportunities, business solutions, analysis of external and internal factors, and then determine the strategic planning. 


\section{Identify Problems and Opportunities a. Customer jobs}

The high number of unemployed, makes them try to find solutions for themselves by means of entrepreneurship. The trend back to nature and the promising stretching of the jamu market, where there is an increase in the turnover of jamu business players and the average consumption of jamu in the community, stimulates business actors to look at the jamu market. Unfortunately, the layoffs of course have minimal capital to start a business. In addition, the lack of knowledge about jamu and health and ignorance of jamu products that can be accepted by the market. The partnership business is one of the business ecosystems that is easy to implement by aspiring entrepreneurs.

\section{b. Customer Pains}

In the jamu partnership business, the customer does not want this business to be unable to operate immediately because he has to prepare many things that are not fully prepared by the jamu partnership company. Customers also have to use the company's brand so that customers who want to use the brand cannot be realized. On the other hand, the stigma of bitter jamu is still attached to the customer's concern if the jamu product cannot be accepted by the market.

\section{c. Customer Gains}

In general, customers who are just starting a business do not have business experience. So that customers will feel satisfied when the partnership company provides good service and provides mentoring as long as it is still a partner. Especially if the collaboration process does not make it difficult for the customer. Customers are also increasingly satisfied, when the price offered is relatively cheap according to their budget. Based on the explanation above, there are four problems that have been identified, namely (1) The high desire for entrepreneurship; (2) The stigma of bitter jamu products and less innovative; (3) It is difficult to be selfemployed, including using your own brand;

(4) The lack of good service and sustainable business cooperation.

\section{Business Solutions}

\section{a. Pains Reliever}

PT OAM provides jamu partnership business that offers several jamu partnership packages. Where from every package taken, the customer can immediately run his business. PT OAM also gives customers the freedom to use their own brand, but with the stipulation that the customer still has to include the PT OAM logo. Customers also don't need to worry because the jamu products sold in each package are delicious, sweet and innovative jamu products.

\section{b. Gains Creator}

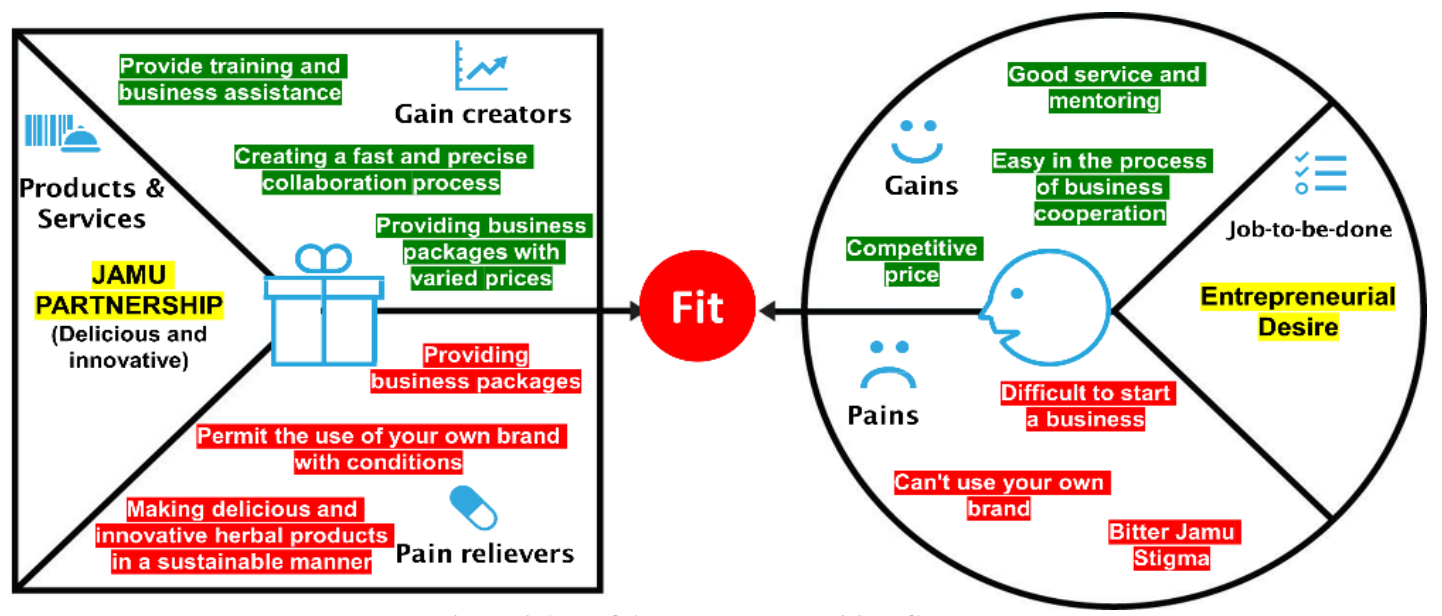

Figure 3.1 PT OAM Value Proposition Canvas.

Source: Author, 2021. 
Erna Setiyawati et.al. Strategic formulation analysis to build a new business startup "jamu partnership" in Indonesia.

$\begin{array}{cccc}\text { PT } & \text { OAM provides updated } \\ \text { information } & \text { services in business }\end{array}$ development, provides training to customers in the field of jamu medicine and business. PT OAM also provides assistance for customers who have just become partners. The partnership process can be done easily and quickly with varied prices. PT OAM provides solutions, namely: (1) Creating a jamu partnership business; (2) Providing delicious, sweet and innovative jamu products (modern, practical, hygienic, attractive and beneficial for health); (3) Creating a cooperation scheme that is easy, fast and can use its own brand; (4) Creating a sustainable relationship in providing services. The results of the identification of problems, opportunities and business solutions are concluded in the value proposition canvas as shown in Figure 3.1 below.
The PT OAM team conducted an analysis of the factors that existed in the jamu partnership business environment, using the framework in Figure 3.2 below.

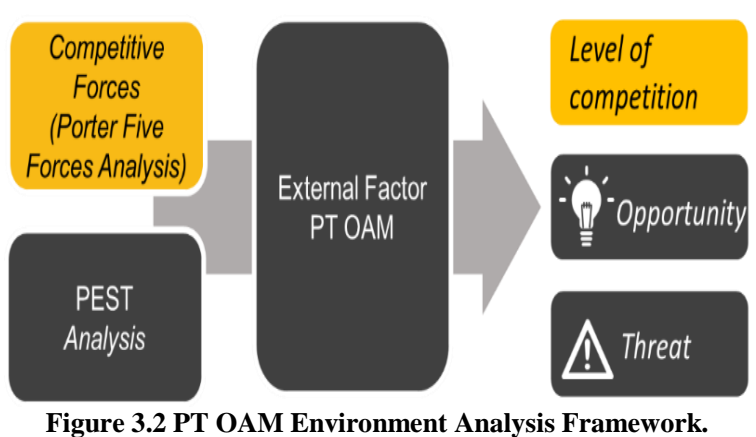
Source: Author, 2021.

\section{a. Competitive Forces}

Based on Figure 3.2 above, the team obtained the results of the competitive forces analysis in the jamu partnership business environment (using the Porter's Five Forces Analysis approach) as shown in Table 3.1 below.

\section{External Factor Analysis}

Table 3.1 PT OAM Porter Five Forces Analysis.
\begin{tabular}{|l|c|c|c|}
\hline Thread of Entry & Weight & Index & Value \\
\hline Trademark & 0.20 & 2 & 0.40 \\
\hline Government regulations & 0.10 & 3 & 0.30 \\
\hline Capital & 0.30 & 1 & 0.30 \\
\hline Product differentiation & 0.25 & 1 & 0.25 \\
\hline Channel & 0.15 & 1 & 0.15 \\
\hline Total Score (Medium) & 0.50 & 1 & 1.40 \\
\hline Number of competitors & 0.30 & 3 & 0.50 \\
\hline Product differentiation & 0.20 & 2 & 0.90 \\
\hline Barriers to exit & 0.40 & 3 & 1.80 \\
\hline Total Score (Medium) & 0.35 & 1 & 0.35 \\
\hline Buyer ability for backward integration & 0.25 & 2 & 0.50 \\
\hline Product differentiation & & 2.05 \\
\hline Switching cost & 0.20 & 2 & 0.40 \\
\hline Total Score (Medium) & 0.30 & 2 & 0.60 \\
\hline Supplier concentration & 0.15 & 1 & 0.15 \\
\hline Supplier product price & 0.35 & 2 & 0.70 \\
\hline Supplier information & 0.60 & 3 & 1.85 \\
\hline Availability of suppliers & 0.40 & 2 & 0.80 \\
\hline Total Score (Medium) & & 2.60 \\
\hline The tendency of buyers to change products & & \\
\hline Relative price and replacement performance & & \\
\hline Total Score (High) & & \\
\hline
\end{tabular}

Source: Author, 2021

The results of the analysis in Table 3.1 above, show that the quantitative value in the range of $1.67-2.33$ is categorized as moderate, namely the jamu partnership business is in fairly tight competition.

\section{b. PEST}

Based on Figure 3.2 above, the team also analyzed the Political, Economic, Social and Technological factors and results of this analysis according to Table 3.2 below. 
Erna Setiyawati et.al. Strategic formulation analysis to build a new business startup "jamu partnership" in Indonesia.

Table 3.2 PT OAM External Factor Analysis (EFE)

\begin{tabular}{|l|c|c|c|}
\hline Key External Factors & Weight & Rating & W-Scored \\
\hline Opportunities & & & \\
\hline Government regulations (Politics). & 0.07 & 4 & 0.28 \\
\hline Decreasing tax rate (Politics) & 0.09 & 3 & 0.27 \\
\hline Increased entrepreneurial desire (Economy). & 0.08 & 3 & 0.24 \\
\hline Big market share (Economy). & 0.10 & 2 & 0.20 \\
\hline Healthy lifestyle trends (Social). & 0.07 & 2 & 0.14 \\
\hline The positive impact of COVID-19 (Social). & 0.06 & 3 & 0.18 \\
\hline Availability of jamu laboratory (Technology). & 0.06 & 3 & 0.18 \\
\hline Digital (Technology). & 0.05 & 2 & 0.10 \\
\hline Threats & & & \\
\hline Complicated integrated licensing (Politics). & 0.06 & 2 & 0.12 \\
\hline Consumer buying decisions (Politics). & 0.08 & 2 & 0.16 \\
\hline Buying power decreases (Economy). & 0.09 & 4 & 0.36 \\
\hline Stigma of jamu bitter (Social). & 0.06 & 2 & 0.12 \\
\hline Lifestyle trends (Social). & 0.08 & 3 & 0.24 \\
\hline Equipment for serving (Technology). & 0.05 & 2 & 0.1 \\
\hline Total Score & $\mathbf{1 . 0 0}$ & & $\mathbf{2 . 6 9}$ \\
\hline
\end{tabular}

Source : Author, 2021.

Based on the analysis results of Table 3.2 above, the total score is 2.69 slightly above the median value of 2.50 . This means that the business can run quite well.

\section{Internal Factor Analysis}

In building a startup business, internal factor analysis is needed so that the business can run well, be able to win the competition and be sustainable. Internal analysis includes what resources and capabilities the company needs. The results of the analysis at this stage can be seen in Table 3.3 below.

Table 3.3 PT OAM Internal Factor Analysis (IFE).

\begin{tabular}{|c|c|c|c|}
\hline Key Internal Factors & Weight & Rating & W-Scored \\
\hline \multicolumn{4}{|l|}{ Strengths } \\
\hline Operational efficiency. & 0.07 & 3 & 0.21 \\
\hline Delicious, sweet and innovative products. & 0.08 & 4 & 0.32 \\
\hline Industry relation. & 0.08 & 4 & 0.32 \\
\hline Distribution. & 0.06 & 3 & 0.18 \\
\hline Partner locations. & 0.08 & 3 & 0.24 \\
\hline Partnership process. & 0.08 & 4 & 0.32 \\
\hline Product innovation. & 0.08 & 4 & 0.32 \\
\hline HR competency. & 0.07 & 4 & 0.28 \\
\hline HR development. & 0.06 & 3 & 0.18 \\
\hline \multicolumn{4}{|l|}{ Weakness } \\
\hline Capital. & 0.07 & 2 & 0.14 \\
\hline Production process. & 0.07 & 2 & 0.14 \\
\hline Brand. & 0.06 & 2 & 0.12 \\
\hline Lack of skilled. & 0.07 & 2 & 0.14 \\
\hline Promotion channels. & 0.07 & 2 & 0.14 \\
\hline Total Score & 1.00 & & 3.05 \\
\hline
\end{tabular}

Table 3.3 above shows that the total score is 3.05 slightly above the median value of 2.50. This means have a strong internal factor position.

\section{Competitive Advantage (VRIO)}

Then based on the strengths value in Table 3.3 above, it is then determined and measured which items can become the company's competitive advantage. That can be seen in Table 3.4 below.

Tabel 3.4 PT OAM VRIO Analysis

\begin{tabular}{|l|c|c|c|c|c|}
\hline \multicolumn{1}{|c|}{ Items } & $\begin{array}{l}\text { Value? } \\
(\mathbf{V})\end{array}$ & $\begin{array}{l}\text { Rare? } \\
(\mathbf{R})\end{array}$ & $\begin{array}{l}\text { Inimitable? } \\
(\mathbf{I})\end{array}$ & $\begin{array}{l}\text { Organized? } \\
(\mathbf{O})\end{array}$ & Impact on competitive advantage \\
\hline Delicious, sweet and innovative products. & Yes & Yes & Yes & Yes & Sustainable competitive advantage. \\
\hline Industry relation. & Yes & Yes & Yes & Yes & Sustainable competitive advantage. \\
\hline Partnership process. & Yes & Yes & Yes & Yes & Sustainable competitive advantage. \\
\hline Product innovation. & Yes & Yes & No & Yes & Temporary competitive advantage. \\
\hline HR competency & Yes & Yes & No & Yes & Temporary competitive advantage. \\
\hline
\end{tabular}


Erna Setiyawati et.al. Strategic formulation analysis to build a new business startup "jamu partnership" in Indonesia.

Based on the results of the analysis in table 3.4, the company has three competitive advantages, namely: (1) Delicious, sweet and innovative products; (2) Industry relation; and (3) Partnership process. This must be maintained and continuously developed so that it becomes an unfair advantage for the company.

\section{Strategic Planning}

Strategic planning is prepared by setting objective at first. The objective of the PT OAM team is to build a jamu partnership startup company with the right business model, so that it can answer the value proposition canvas.

\section{a. CPM}

After determining the value of EFE and IFE, then a competitive profile matrix is compiled to determine the potential of the strongest competitor companies as which can be seen in table 3.5 below.

Tabel 3.5 PT OAM Competitive Profile Matrix (CPM).

\begin{tabular}{|c|c|c|c|c|c|c|c|c|}
\hline \multirow[t]{2}{*}{ No } & \multirow[t]{2}{*}{ Critical Success Factor } & \multirow[t]{2}{*}{ Weight } & \multicolumn{2}{|c|}{ PT OAM } & \multicolumn{2}{|c|}{ Sido Muncul } & \multicolumn{2}{|c|}{ Merapi Farma } \\
\hline & & & Rating & Score & Rating & Score & Rating & Score \\
\hline 1 & Price & 0.20 & 3 & 0.60 & 3 & 0.60 & 3 & 0.60 \\
\hline 2 & Product taste & 0.18 & 4 & 0.72 & 3 & 0.54 & 2 & 0.36 \\
\hline 3 & Business Relations & 0.17 & 3 & 0.51 & 4 & 0.68 & 3 & 0.51 \\
\hline 4 & Partnership & 0.15 & 4 & 0.60 & 3 & 0.45 & 3 & 0.45 \\
\hline 5 & Innovation & 0.16 & 3 & 0.48 & 4 & 0.64 & 3 & 0.48 \\
\hline 6 & Competence & 0.14 & 3 & 0.42 & 4 & 0.56 & 3 & 0.42 \\
\hline & Total Score & 1.00 & & 3.33 & & 3.47 & & 2.82 \\
\hline
\end{tabular}

The results of the CPM data above show that PT Sido Muncul is a very strong potential competitor at this time.

\section{SWOT Matrix}

Furthermore, the SWOT matrix was compiled by the team to find the right strategy, as in the Table 3.6 below.

Tabel 3.6 PT OAM SWOT Matrix.

\begin{tabular}{|c|c|c|c|}
\hline & & $\mathbf{S}$ & W \\
\hline & $\begin{array}{l}\text { OT } \\
\text { ngths - Weaknesses - Opportunities - Threats }\end{array}$ & $\begin{array}{l}\text { 1. Operational efficiency. } \\
\text { 2. Delicious, sweet and innovative products. } \\
\text { 3. Industry relation. } \\
\text { 4. Distribution. } \\
\text { 5. Partner locations. } \\
\text { 6. Partnership process. } \\
\text { 7. Product innovation. } \\
\text { 8. HR competency. } \\
\text { 9. HR development. }\end{array}$ & $\begin{array}{ll}\text { 1. } & \text { Capital. } \\
\text { 2. } & \text { Production process. } \\
\text { 3. } & \text { Brand. } \\
\text { 4. } & \text { Lack of skilled. } \\
\text { 5. } & \text { Promotion channels. }\end{array}$ \\
\hline O & $\begin{array}{l}\text { 1. Government regulations (Politics). } \\
\text { 2. Decreasing tax rate (Politics). } \\
\text { 3. Increased entrepreneurial desire (Economy). } \\
\text { 4. Big market share (Economy). } \\
\text { 5. Healthy lifestyle trends (Social). } \\
\text { 6. The positive impact of COVID-19 (Social). } \\
\text { 7. Availability of jamu laboratory (Technology). } \\
\text { 8. Digital (Technology). }\end{array}$ & $\begin{array}{l}\text { Strategi SO } \\
\text { 1. Conducting offline and online promotions with } \\
\text { various parties (S3,S4,S7,S9,O1, O3,O4,O5,O6,O8). } \\
\text { 2. Cooperating with ABGC (S1,S3,S6,S8, } \\
\mathrm{S} 9, \mathrm{O} 1, \mathrm{O} 2, \mathrm{O} 3, \mathrm{O} 4, \mathrm{O} 8) \text {. } \\
\text { 3. Provide offline partnership with ease of } \\
\text { transaction.(S1,S4,S5,S6,O3,O4,O5,O6). } \\
\text { 4. Create training programs, employee development and } \\
\text { product innovation (S2,S7, S8,S9,O7,O8). }\end{array}$ & $\begin{array}{l}\text { Strategi WO } \\
\text { 1. Do branding partnerships and products } \\
\text { (W2, W3, W5, O3, O4, O5, O6, O8). } \\
\text { 2. Cooperating with the tolling industry } \\
\text { (W1, W2, W4, O1, O7). } \\
\text { 3. Conduct rigorous selection and } \\
\text { recruitment to meet the company's HR } \\
\text { (W4, O6). } \\
\text { 4. Take advantage of deferred tax payments } \\
\text { (W1,O2). }\end{array}$ \\
\hline $\mathbf{T}$ & $\begin{array}{l}\text { 1. Complicated integrated licensing (Politics). } \\
\text { 2. Consumer buying decisions (Politics). } \\
\text { 3. Buying power decreases (Economy). } \\
\text { 4. Stigma of jamu bitter (Social). } \\
\text { 5. Lifestyle trends (Social). } \\
\text { 6. Equipment for serving (Technology). }\end{array}$ & $\begin{array}{l}\text { Strategi ST } \\
\text { 1. Creating innovative herbal products that are delicious, } \\
\text { sweet, healthy, easy to consume and affordable. } \\
\text { (S2,S3,S7,S8,T2,T3,T4,T5,T6). } \\
\text { 2. Choose a towing industry that already has a permit } \\
\text { (S1,S3,S7,S6,S8,T1,T6). } \\
\text { 3. Open a representative office (S1,S4,S5,S6,T2,T3,T5). } \\
\text { 4. Develop HR capabilities in negotiation, digital and } \\
\text { persuasive marketing (S8, T2, T4, T5). }\end{array}$ & \begin{tabular}{ll} 
& \multicolumn{1}{c}{ Strategi WT } \\
1. Establish cooperation with finance \\
companies (W1, T2, T3). \\
2. Cooperating with LKP Jamu (W4, T6). \\
3. Use freelance influencers. \\
(W3,W4,W5,T2,T3,T4,T5). \\
4. Establish a Home Industry Company / \\
PIRT (W2,W3,T1,T2,T3).
\end{tabular} \\
\hline
\end{tabular}

Source: Author, 2021. 
Based on the SWOT analysis, three strategies were obtained, namely: (1) Product innovation and partnership (SO3,SO4,WO2,ST1,ST2,WT2); (2) market penetration (SO1, SO2, WO1, WO3, ST3, ST4 ,WT3,WT4); and (3) Looking for investors (WO4,WT1).

\section{IE Matrix}

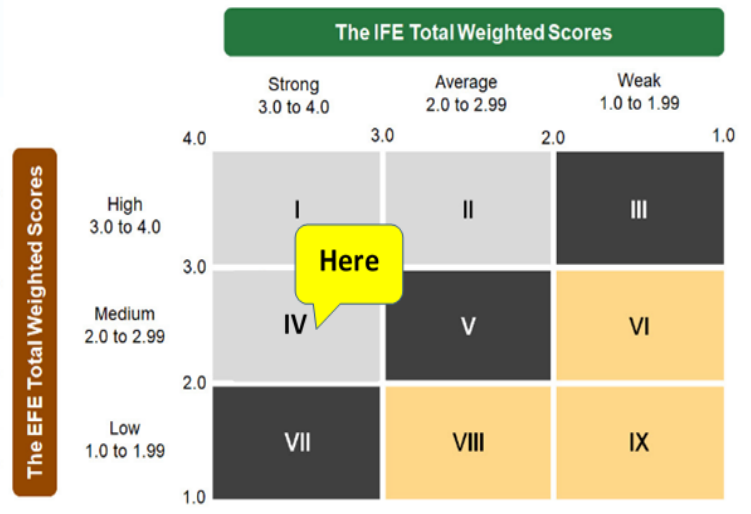

The IE matrix analysis is done by comparing the EFE value of 2.69 and IFE value of 3.05 , as shown in the following Figure 3.3.

PT OAM startup business is in cell IV, so the company can use an intensive strategy (market penetration, market development, and product development) or backward, forward and horizontal integration.

\section{QSPM Matrix}

Based on the results of the SWOT matrix (Table 3.6) and the IE matrix (Figure 3.3 ), team determines two alternative strategies that can choose, first is product development strategy through product innovation and partnerships, and second is market penetration strategies as shown in Table 3.7 QSPM matrix below.

Figure 3.3 PT OAM IE Matrix Analysis. Source: Author, 2021.

Table 3.7 PT OAM QSPM Matrix.

\begin{tabular}{|c|c|c|c|c|c|}
\hline \multirow[b]{2}{*}{ Key Factors } & \multirow[b]{2}{*}{ Weight } & \multicolumn{2}{|c|}{$\begin{array}{c}\text { Product } \\
\text { Development }\end{array}$} & \multicolumn{2}{|c|}{$\begin{array}{c}\text { Market } \\
\text { Penetration }\end{array}$} \\
\hline & & AS & TAS & AS & TAS \\
\hline \multicolumn{6}{|l|}{ Opportunities } \\
\hline Government regulations (Politics). & 0.035 & 4 & 0.140 & 4 & 0.140 \\
\hline Decreasing tax rate (Politics) & 0.045 & & & 3 & 0.135 \\
\hline Increased entrepreneurial desire (Economy). & 0.040 & 3 & 0.120 & 3 & 0.120 \\
\hline Big market share (Economy). & 0.050 & 2 & 0.100 & 2 & 0.100 \\
\hline Healthy lifestyle trends (Social). & 0.035 & 2 & 0.070 & 2 & 0.070 \\
\hline The positive impact of COVID-19 (Social). & 0.030 & 3 & 0.090 & 3 & 0.090 \\
\hline Availability of jamu laboratory (Technology). & 0.030 & 3 & 0.090 & & \\
\hline Digital (Technology). & 0.025 & 2 & 0.050 & 2 & 0.050 \\
\hline \multicolumn{6}{|l|}{ Threats } \\
\hline Complicated integrated licensing (Politics). & 0.030 & 2 & 0.060 & 2 & 0.060 \\
\hline Consumer buying decisions (Politics). & 0.040 & 2 & 0.080 & 2 & 0.080 \\
\hline Buying power decreases (Economy). & 0.045 & 4 & 0.180 & 4 & 0.180 \\
\hline Stigma of jamu bitter (Social). & 0.030 & 2 & 0.060 & 2 & 0.060 \\
\hline Lifestyle trends (Social). & 0.040 & 3 & 0.120 & 3 & 0.120 \\
\hline Equipment for serving (Technology). & 0.025 & 2 & 0.050 & & 0.000 \\
\hline \multicolumn{6}{|l|}{ Strengths } \\
\hline Operational efficiency. & 0.035 & 3 & 0.105 & 3 & 0.105 \\
\hline Delicious, sweet and innovative products. & 0.040 & 4 & 0.160 & & \\
\hline Industry relation. & 0.040 & 4 & 0.160 & 4 & 0.160 \\
\hline Distribution. & 0.030 & 3 & 0.090 & 3 & 0.090 \\
\hline Partner locations. & 0.040 & 3 & 0.120 & 3 & 0.120 \\
\hline Partnership process. & 0.040 & 4 & 0.160 & 4 & 0.160 \\
\hline Product innovation. & 0.040 & 4 & 0.160 & & \\
\hline HR competency. & 0.035 & 4 & 0.140 & 4 & 0.140 \\
\hline HR development. & 0.030 & 3 & 0.090 & 3 & 0.090 \\
\hline \multicolumn{6}{|l|}{ Weaknesses } \\
\hline Capital. & 0.035 & 2 & 0.070 & & \\
\hline Production process. & 0.035 & 2 & 0.070 & 2 & 0.070 \\
\hline Brand. & 0.030 & & & 2 & 0.060 \\
\hline Lack of skilled. & 0.035 & 2 & 0.070 & 2 & 0.070 \\
\hline Promotion channels. & 0.035 & & & 2 & 0.070 \\
\hline Total Score & 1.000 & & 2.61 & & 2.34 \\
\hline
\end{tabular}

Source: Author, 2021. 

Indonesia.

Base on the QSPM matrik, product development strategy was chosen as the main strategy because it has the highest score of 2.61. Furthermore, looking at the results of Competitive Force, SWOT, IE and QSPM Matrix. The strategy chosen is the
Differentation Focus Strategy. Because by implementing this strategy, it is expected to reduce the threat of competition by offering product innovations that are different and more attractive than competitors. This can be seen in Figure 3.4 below.

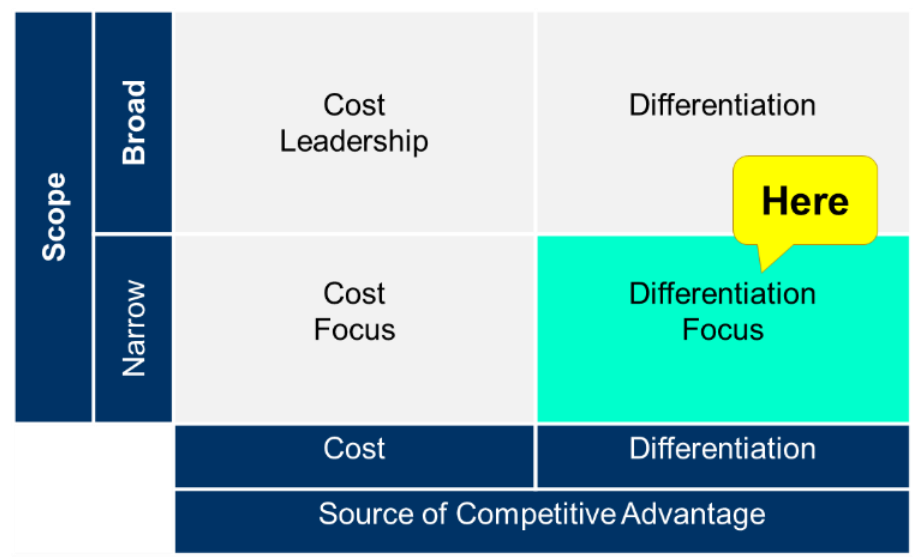

Figure 3.4 PT OAM Porter's Generic Strategy.

Source: Author, 2021.

The final stage in building a startup business is to determine the lean business model canvas. Figure 3.5 below shows PT
OAM lean business model canvas, which was compiled based on the previous analysis.

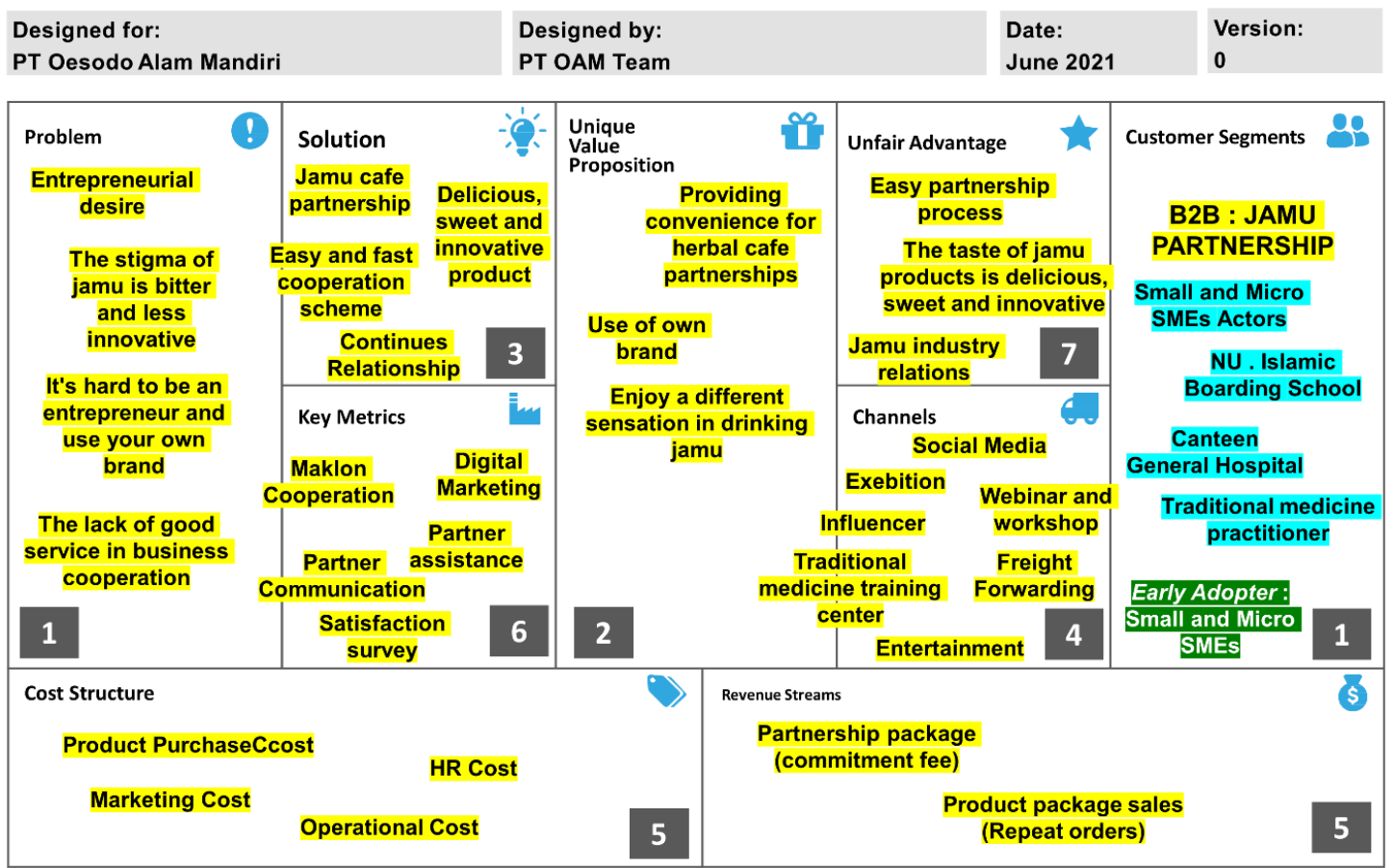

Figure 3.5 PT OAM Lean Business Canvas Model Source: Author, 2021.

\section{CONCLUSION}

Looking at the results of the existing analysis, starting with determining the value proposition canvas, analyzing external and internal business factors. Then proceed with matrix analysis of CPM, SWOT, IE, QSPM, and Porter's Generic Strategy, so this jamu partnership startup business can be built properly. In the end, the business activities carried out must submit to the lean business 
model canvas (see Figure 3.5) that has been determined so that the business can be competitive and sustainable. In addition, product development strategies and focus differentiation must continue to be evaluated and developed. Strategy formulation activities and evaluation of the lean business model canvas must be carried out regularly, considering the current condition of VUCA era, where the external business environment is changing very quickly.

\section{Acknowledgement: None}

\section{Conflict of Interest: None}

\section{Source of Funding: None}

\section{REFERENCES}

1. Arifin, F. A. S., Yanuar, T., Syah, R., Indradewa, R., \& Pusaka, S. (2019). Sales and Marketing Strategies Duck Nugget Product Using Porter's Five Force and SWOT Analysis. Journal of Multidisciplinary Academic, 03(04).

2. Barnes, C., Blake, H., \& Pinder, D. (2009). Creating and delivering your value proposition: Managing customer experience for profit. Kogan Page Publishers.

3. Choe, J. M. (2003). The effect of environmental uncertainty and strategic applications of IS on a firm's performance. Information and Management, 40(4), 257268 . https://doi.org/10.1016/S03787206(02)00008-3.

4. Chung, W., Chen, H., \& Nunamaker, J. F. (2005). A visual framework for knowledge discovery on the web: An empirical study of business intelligence exploration. Journal of Management Information Systems, 21(4), 57-84.

https://doi.org/10.1080/07421222.2005.110 45821.

5. Clark, T., Osterwalder, A., \& Pigneur, Y. (2012). Business model you: A one-page method for reinventing your career. John Wiley \& Sons.

6. Contoyannis, P., \& Jones, A. M. (2004). Socio-economic status, health and lifestyle.
Journal of health economics, 23(5), 965995.

7. Fred R. David. (2012). Strategic Management and Business Policy Globalization, Innovation and Sustainability Fifteenth Edition. In Foreign Affairs (Vol. 91).

https://doi.org/10.1017/CBO978110741532 4.004.

8. Haq, D. U., \& Indradewa, R. (2020). Strategic Formulation Analysis of Virtual Gas Pipeline Business Development ( CNG \& LNG ). 7(December), 57-65.

9. Kurniawan, H., Yanuar, T., Syah, R., Indradewa, R., \& Fajarwati1, D. (2020). Human Capital Strategy Implementation for Start-up Business Over Islamic Boarding Schools Noor Halal Minimarket. Journal of Multidisciplinary Academic, 4(3), 194-198. Retrieved from https://kemalapublisher.com/index.php/JoM A/article/view/468.

10. Lindič, J., \& Da Silva, C. M. (2011). Value proposition as a catalyst for a customer focused innovation. Management Decision.

11. Loke Fristanto, Syah, T. Y. R., Indradewa, R., \& Fajarwati, D. (2020). The Implementation of Marketing Mix Strategy for Medical Hazardous Waste Processing Companies During Competition Existing Companies over PT . Kelola Lingkungan Kita. Journal of Multidisciplinary Academic, 4(6), 426-430.

12. Osterwalder, A. (2014). Value proposition design : how to create products and services customers want: get started with. How to Create Products and Services Customers Want, 290.

13. Robert M. Grant. (2010). Contemporary Strategy Analysis. John Wiley \& Sons Ltd.

14. Saputra, A., Indradewa, R., Yanuar, T., \& Syah, R. (2021). Risk Management Application for Business Startups " Jamu Partnership " in Indonesia. 8(August), 148155.

How to cite this article: Setiyawati E, Saputra A, Indradewa $\mathrm{R}$ et.al. Strategic formulation analysis to build a new business startup "jamu partnership" in Indonesia. International Journal of Research and Review. 2021; 8(8): 568-576. DOI: https://doi.org/10.52403/ijrr.20210876 